which may make these house officers more error prone.

The house officers in this study were mainly graduates of the University of Newcastle upon Tyne where, until recently, students were expected to learn procedures for giving intravenous drugs during their clinical attachments. Our second survey indicates that in this method of instruction Newcastle Medical School was no different from most other medical schools in Britain, $70 \%$ of which have a similar approach and only one of which tests student's ability in this area.

It seems incorrect to assume that medical students learn the practicalities of parenteral drug administration during their clinical attachments. Some changes have therefore recently been introduced both at the Newcastle Medical School and within the hospitals of the Northern region. The undergraduate course has been modified to include instruction on procedural

aspects of drug administration. The production of a teaching video and a teaching session in the practical skills laboratory are now proposed. In addition, all hospitals in the region employing preregistration house officers now hold mandatory induction courses which include instruction on giving parenteral drugs.

We wish to acknowledge helpful discussions with Professors M D Rawlins, L J Donaldson, and J Anderson.

1 Leslie PJ, Williams JA, McKenna C, Smith G, Heading RC. Hours, volume and type of work of preregistration house officers. $B M Y$ 1990;300:1038-41. Bain PG, Teh WL, Rowe TJ. Work load of preregistration house officers. $B M Y$ 1990;300:1463.

3 Cunningham S, Ventors G, Dobson A, Robertson N. Workload of preregistration house officers. $B M \mathcal{F} 1990 ; 300: 1342$.

4 Dyer C. Manslaughter convictions for making mistakes. BMf 1991;303:1218.

5 Tomford JW, Hershey CO, McLaren CE, Porter DK, Cohen DI. Intravenous therapy team and peripheral venous cathether associated complications. Arch Intern Med 1984;144:1 191-4.

(Accepted 14 fune 1993)

\title{
Compliance with standardised assessment scales for elderly people among consultant geriatricians in Wessex
}

\section{Rebecca B Dunn, P A Lewis}

\section{St Martin's Hospital, Bath BA2 5RP}

Rebecca B Dunn, consultant

Department of Medical Computing and Statistics, University of Wales College of Medicine, Cardiff CF4 4XN

P A Lewis, senior lecturer in health informatics

Correspondence to: Dr Dunn.

$B M \mp 1993 ; 307: 606$ in geriatric medicine

In June 1992 the Royal College of Physicians of London and the British Geriatrics Society recommended a set of standardised assessment scales for elderly patients. ${ }^{1}$ Further support for these scales has been published. ${ }^{2}$

Encouraged by this peer sponsorship the geriatricians in Wessex agreed to use two of the scales to assess their patients on admission and discharge. These were the abbreviated mental test for assessing cognitive function and the Barthel index for assessing the ability to perform primary activities of daily living, including feeding, grooming, dressing, and mobility. We describe the compliance with these guidelines among the consultants in geriatric medicine in the region.

\section{Patients, methods and results}

All 40 consultant geriatricians in Wessex participated in this study. The sample was set at 1100 consecutive inpatient discharges from the acute or assessment wards of the 11 departments in which the consultants worked. The table shows the audit indicator in the format used in the Wessex region. ${ }^{3}$

A coding form for the abbreviated mental test and Barthel index and standard instructions on how to carry out the assessments were produced and sent to each department. Liaison geriatricians were responsible for organising the project in their departments;

Specification of audit indicator used in study

\begin{tabular}{|c|c|c|}
\hline Aspect & Exceptions & Definitions and instructions \\
\hline $\begin{array}{l}\text { All geriatric patients } \\
\text { admitted to acute } \\
\text { or assessment } \\
\text { wards to have } \\
\text { abbreviated mental } \\
\text { test and Barthel } \\
\text { index` recorded } \\
\text { (a) on admission } \\
\text { and }(b) \text { on } \\
\text { discharge } \\
\text { Standard: } 100 \%\end{array}$ & $\begin{array}{l}\text { (a) Patients who are } \\
\text { admitted and die } \\
\text { (b) Patients discharged on } \\
\text { day of admission or } \\
\text { before end of next } \\
\text { working day } \\
\text { (c) Patients who discharge } \\
\text { themselves } \\
\text { (d) Patients transferred from } \\
\text { acute or assessment } \\
\text { geriatric beds to non- } \\
\text { acute geriatric beds } \\
\text { (e) Patients transferred to } \\
\text { another specialty }\end{array}$ & $\begin{array}{l}\text { Admission to acute or assessment ward }=\text { Körner data } \\
\text { method of admission. E= Emergency } \\
\text { Abbreviated mental test and Barthel index on specific } \\
\text { form in case notes } \\
\text { Date of admission any time from } 1 \text { June } 1992 \\
\text { Date of discharge between } 1 \text { July } 1992 \text { and } 30 \\
\text { September } 1992 \\
\text { For tests to qualify as on admission patient should have } \\
\text { been tested on day of admission or before end of next } \\
\text { working day } \\
\text { For tests to qualify as on discharge patient should have } \\
\text { been tested on day of discharge or preceding working } \\
\text { day }\end{array}$ \\
\hline
\end{tabular}

*Assessment of performance of primary activities of daily living. they had the freedom to implement the assessments to take account of local circumstances. In each department an audit assistant, working under the supervision of the liaison geriatrician, completed a data collection form for each of 100 consecutive discharges with a data collection system of proved efficiency. ${ }^{4}$

Ten of the 11 departments returned a total of 958 data collection forms by the deadline. In only 190 of these was there compliance with the audit indicatorthat is, both the abbreviated mental test and the Barthel index were completed on admission and on discharge. The compliance of individual consultants ranged from 0 to $100 \%$.

\section{Comment}

Although all departments of geriatric medicine in Wessex had endorsed the guidelines of the Royal College of Physicians and British Geriatrics Society, only a few consultants changed their clinical practice accordingly. This raises important issues in the voluntary standardisation of the delivery of medical care.

No simple assessment method will be perfect, but if such methods cannot be widely implemented, at least to achieve standardisation, then the acceptability of more complex, resource intensive methods is problematical.

Standardisation is an important factor in the contracting process. Purchasers might require these assessments to be used to monitor the appropriateness of admissions and the value of stays in hospital.

The sponsorship of these assessments by the Royal College of Physicians and the British Geriatrics Society means that arguing against their use and hence their inclusion as an integral part of a contract for the care of elderly people is difficult. Good compliance with peer sponsored standards is crucial to achieving high quality clinical care. Monitoring and assuring compliance deserve more attention in audit. Although no general conclusions can be drawn from our study of one specialty in one region, the findings should prompt early action to ascertain whether they are representative.

This project was supported by Wessex region's geriatrics specialist subcommittee and funded by its audit committee. The coding forms and instructions are available (in electronic form if a PC disk is enclosed) from RBD.

1 Working Group of the Royal College of Physicians and the British Geriatrics Society. Standardised assessment scales for elderly people. London: Royal College of Physicians, 1992

2 Rodgers $H$, Curless $R$, James OFW. Standardised functional assessment scales for elderly patients. Age Ageing 1993;22:161-3.

3 Dixon N. Medical audit primer. Ower: Healthcare Quality Quest, 1991.

4 Lewis PA, Charny M. A low cost, simple technology system for district-wide audit. British fournal of Health Care Computing 1992;9:36.

(Accepted 17 fune 1993) 